\title{
SIMULASI TUMBUKAN PARTIKEL GAS IDEAL DENGAN MODEL CELLULAR AUTOMATA DUA DIMENSI
}

\begin{abstract}
Annisa Mujriati ${ }^{(1)}$, Abdul Basid ${ }^{(2)}$
Abstrak : Telah dilakukan simulasi tumbukan partikel gas ideal dengan menggunakan model cellular automata dua dimensi untuk memvisualisasikan tumbukan partikel gas ideal. Tumbukan partikel disimulasikan dengan menggunakan model cellular automata dua dimensi. Di dalam cellular automata, pergerakan partikel diatur dengan suatu aturan yaitu aturan delapan tetangga yang merupakan aturan acak. Hasil program simulasi tumbukan partikel gas ideal dengan model cellular automata dua dimensi menggunakan aturan acak delapan tetangga ini berbasis Delphi adalah arah tumbukan partikel gas sesuai dengan sifat-sifat gas ideal yang bergerak acak dan tersebar merata dalam jumlah yang banyak serta sebagian tumbukannya itu bersifat lenting sempurna. Sesuai dengan konsep cellular automata program simulasi tumbukan partikel gas ideal ini menyerupai bentuk yang ada di alam.
\end{abstract}

Kata Kunci: Tumbukan, Partikel, Gas Ideal, Cellular Automata

\section{PENDAHULUAN}

Pada awalnya terdapat suatu pemikiran bahwa semua aturan berdasarkan pada persamaan matematis dapat digunakan untuk mendeskripsikan segala keadaan di dunia. Kemudian diperkenalkan sebuah ilmu baru yang bergantung pada aturan yang lebih umum yang dapat diwujudkan dengan program komputer yang sederhana. Stephen Wolfram (2002: 1) menyatakan bahwa dalam program sederhana tersebut terdapat keuniversalan yang dapat menguraikan semua fenomena yang ada di alam dengan model cellular automata, misalnya mencari bentuk daun, bentuk kristal salju, pola kulit binatang, dan bentuk-bentuk artistik. Stephen Wolfram meyakini bahwa dengan mengembangkan ilmu ini maka dapat dibangun sebuah dasar dari semua teori fisika, dimana ruang, waktu, mekanika kuantum dan bentuk yang ada di dunia disatukan.

Untuk itu penulis mencoba membuat program simulasi tumbukan partikel gas ideal yang berdasarkan sifat- sifat gas ideal dengan menggunakan model cellular automata dua dimensi yang mana permasalahannya adalah bagaimana simulasi tumbukan partikel gas ideal dengan menggunakan model cellular automata dua dimensi dan apakah dapat dihasilkan program simulasi yang menggunakan model cellular automata dua dimensi untuk menvisualisasikan tumbukan partikel gas ideal. Mengingat pentingnya pembuatan program simulasi ini, maka tujuannya adalah untuk mensimulasikan tumbukan partikel gas ideal dengan menggunakan model cellular automata dua dimensi dan untuk menghasilkan program simulasi yang menggunakan model cellular automata dua dimensi untuk memvisualisasikan tumbukan partikel gas ideal, dengan harapan dapat digunakan sebagai dasar untuk memahami tumbukan partikel gas ideal dan

\footnotetext{
1,2 Jurusan Fisika UIN Maulana Malik Ibrahim Malang
} 
memahami model cellular automata. Pembuatan program ini merupakan sarana untuk mengembangkan dan mengaplikasikan keilmuan fisika yang telah dipelajari khususnya bidang fisika komputasi.

\section{KAJIAN TEORI}

Tumbukan diartikan sebagai interaksi yang dahsyat antara dua benda yang berlangsung apada waktu yang relatif singkat (Zemansky, 2002). Definisi tumbukan sebagai interaksi yang terjadi dalam waktu $\Delta t$ yang dapat diabaikan terhadap lamanya waktu pengamatan sistem juga dapat dicirikan sebagai peristiwa dengan gaya eksternal yang bekerja pada sistem dapat diabaikan bila dibandingkan dengan gaya tumbukan impulsif. Misalnya ketika pemukul memukul baseball atau tongkat golf memukul bola golf atau satu bola billiard menumbuk yang lainnya, ada gaya eksternal yang bekerja pada sistem, misalnya gravitasi atau gesekan (Halliday, 1999).

Gas ideal merupakan suatu model yang digunakan dalam teori kinetik gas. Anggapan mikroskopis gas ideal untuk model ini adalah sebagai berikut (Sumarjono, 2005):

a. Jumlah partikel gas (N) sangat banyak sekali

b. Partikel-partikel gas tersebar merata dan gerakannya acak.

c. Jarak antar partikel gas jauh lebih besar dari pada ukuran partikel gas.

d. Gaya antar partikel gas hanya bekerja jika terjadi tumbukan.

e. Semua tumbukan yang terjadi, baik tumbukan antar partikel maupun tumbukan antara partikel dengan dinding wadah adalah elastis sempurna.

f. Berlaku hukum-hukum gerak Newton.

Cellular automata dikenalkan oleh Ulan dan Von Neumann pada tahun 1940-an itu yang dijadikan dasar untuk menyelidiki fenomena dan bersifat kompleks. Cellular automata juga dikenal sebagai suatu model untuk membuat program visualisasi komputer yang berhubungan dengan ilmu-ilmu alam. Stephen Wolfram melalui bukunya yang berjudul $A$ New Kinds of science merupakan model cellular automata yang diterapkan dalam berbagai fenomena alam seperti perkembangan kristal salju, bentuk daun, model kulit binatang serta berbagai hal lainnya. Cellular automata merupakan sistem yang dinamis dalam ruang dan waktu yang diskrit. Cellular automata dua dimensi adalah sistem yang berjalan dari waktu ke waktu dan dipengaruhi oleh sel tetangga yang berada di kanan-kiri, atas-bawah dari sel yang ditinjau. Cellular automata mengandung kisi sel yang mana setiap kisi sel dapat menjadi satu jumlah kecil keadaan yang mungkin, yang berubah tiap satuan waktu menyesuaikan dengan keadaan sekitar (Rujuk, 2006).

\section{METODOLOGI PENELITIAN}

Penelitian ini dilakukan di Laboratorium Fisika Komputasi UIN Maulana Malik Ibrahim Malang pada bulan Februari-Maret 2010. Alat yang digunakan dalam penelitian ini adalah: 
a) Perangkat keras (Hardware) dengan Personal Computer (PC) Intel Pentium Dual Core 2.16 GHz, Hardisk 160 GB, Memori 2 GB dan Sistem Operasi Microsoft Windows XP Professional program.

b) Perangkat lunak (Sofware) Borland Delphi versi 7,0 untuk membuat program simulasi tumbukan partikel gas ideal menggunakan model Cellular Automata dua dimensi.

Adapun rancangan penelitian ini adalah sebagai berikut:

1. Penelitian ini akan dilakukan simulasi tumbukan partikel gas ideal dengan model Cellular automata 2 dimensi dengan aturan 8 tetangga.

2. Aturan tetangga yang dipakai dalam pembuatan program simulasi ini ditunjukkan oleh gambar berikut:

\begin{tabular}{|l|l|l|}
\hline 8 & 1 & 2 \\
\hline 7 & & 3 \\
\hline 6 & 5 & 4 \\
\hline
\end{tabular}

\section{Gambar 1: Bentuk Aturan 8 Tetangga Cellulara Automata}

3. Berdasarkan aturan 8 tetangga di atas aturan tumbukan partikel yang dipakai dalam simulasi program ini ditunjukkan oleh gambar berikut:
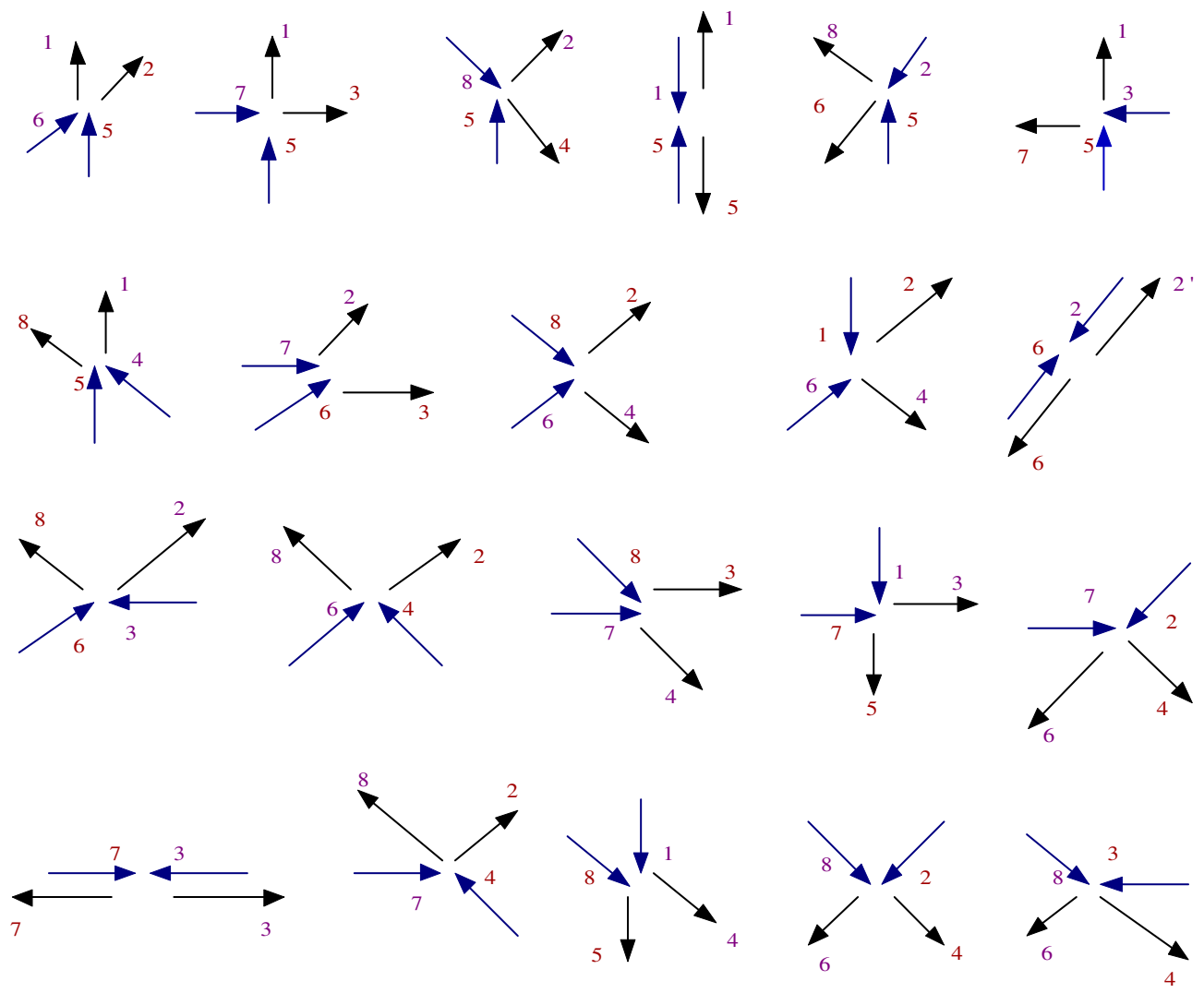

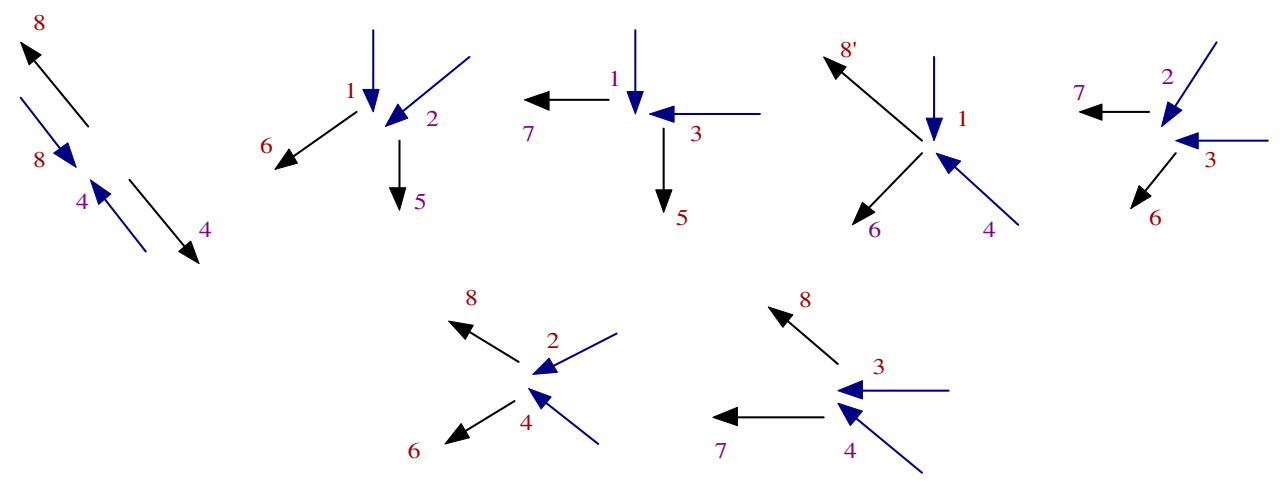

\section{Gambar 2: Aturan Tumbukan Partikel}

4. Gambar 2 menjelaskan aturan-aturan yang dipakai dalam simulasi tumbukan partikel gas ideal. Arah tumbukannya ditunjukkan dengan tanda panah. Tanda panah warna biru adalah partikel yang bertumbukan dan tanda panah warna hitam merupakan arah dari hasil tumbukan antara dua partikel yang diberi lambang dengan tanda panah warna biru. Sedangkan angka-angka itu adalah angka yang berdasarkan penyerderhanaan dari bentuk aturan 8 tetangga cellular automata .

5. Partikel akan bergerak secara acak jika bertumbukan dengan dinding pembatas dan antar partikel. Gerak acak partikel ke arah horisontal (kiri dan kanan), vertikal (atas dan bawah), dan diagonal (menyilang).

Algoritma program simulasi tumbukan partikel gas ideal adalah sebagai berikut:

a. Menentukan jumlah partikel awal.

b. Menempatkan partikel secara acak.

c. Menggerakkan partikel secara acak. Gerak acak ke arah horisontal (kiri dan kanan), vertikal (atas dan bawah), dan diagonal (menyilang).

Flowchart program simulasi tumbukan partikel gas ideal dengan menggunakan model cellular automata seperti pada Gambar berikut: 

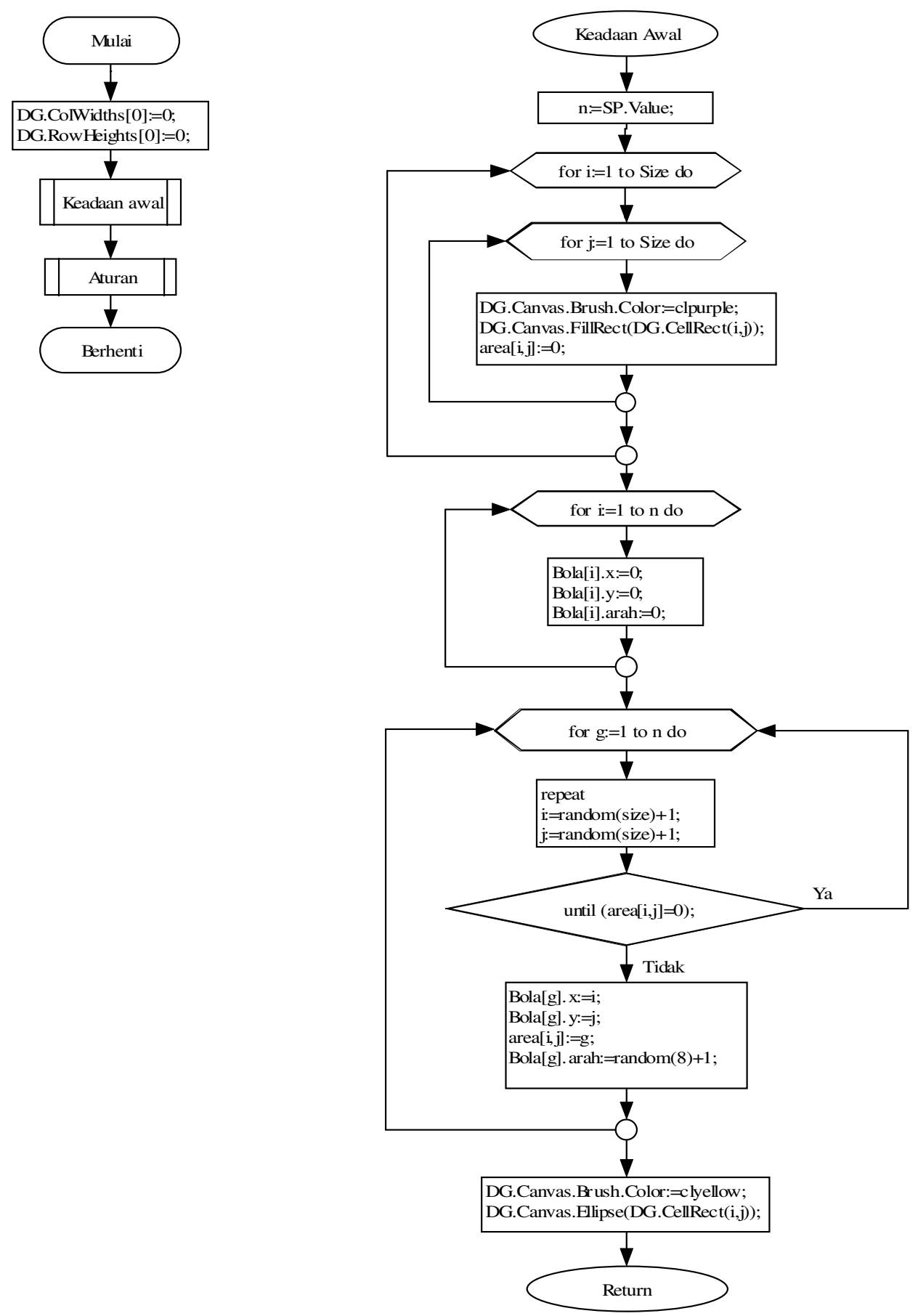

Gambar 3:Flowchart Prosedur Program simulasi Tumbukan Partikel Gas Ideal 


\section{Hasil Program}

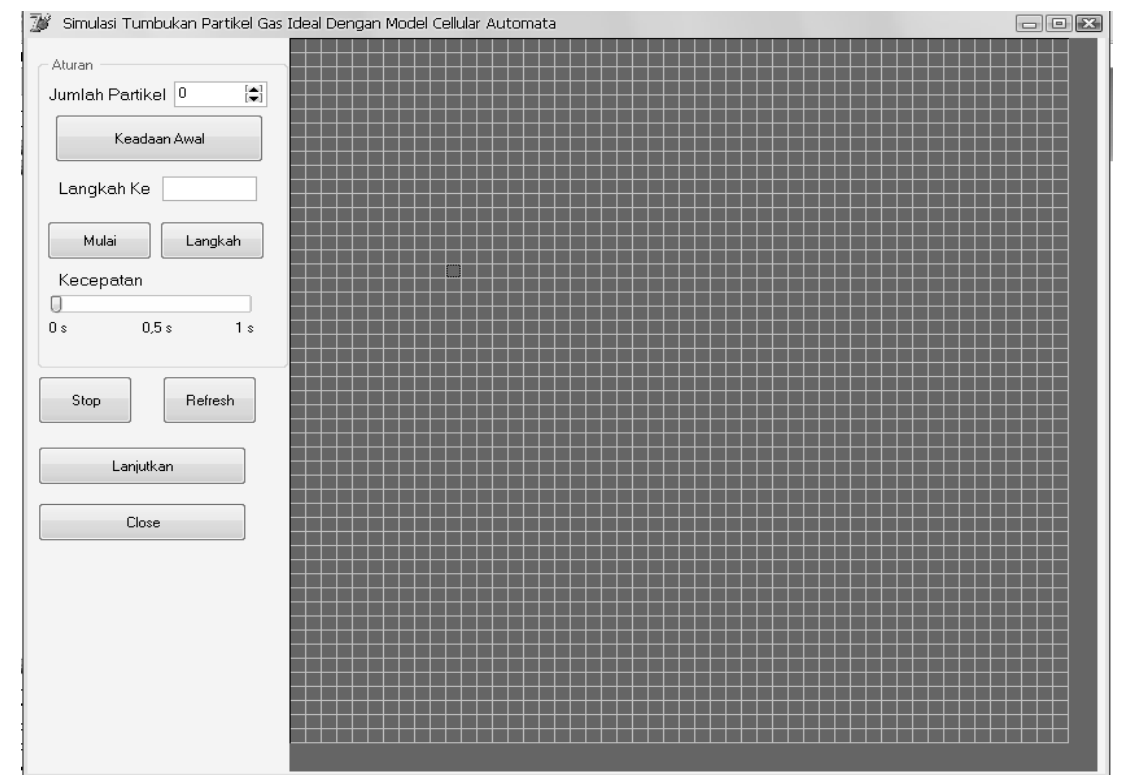

Gambar 4: Tampilan Awal Simulasi Tumbukan Partikel Gas Ideal

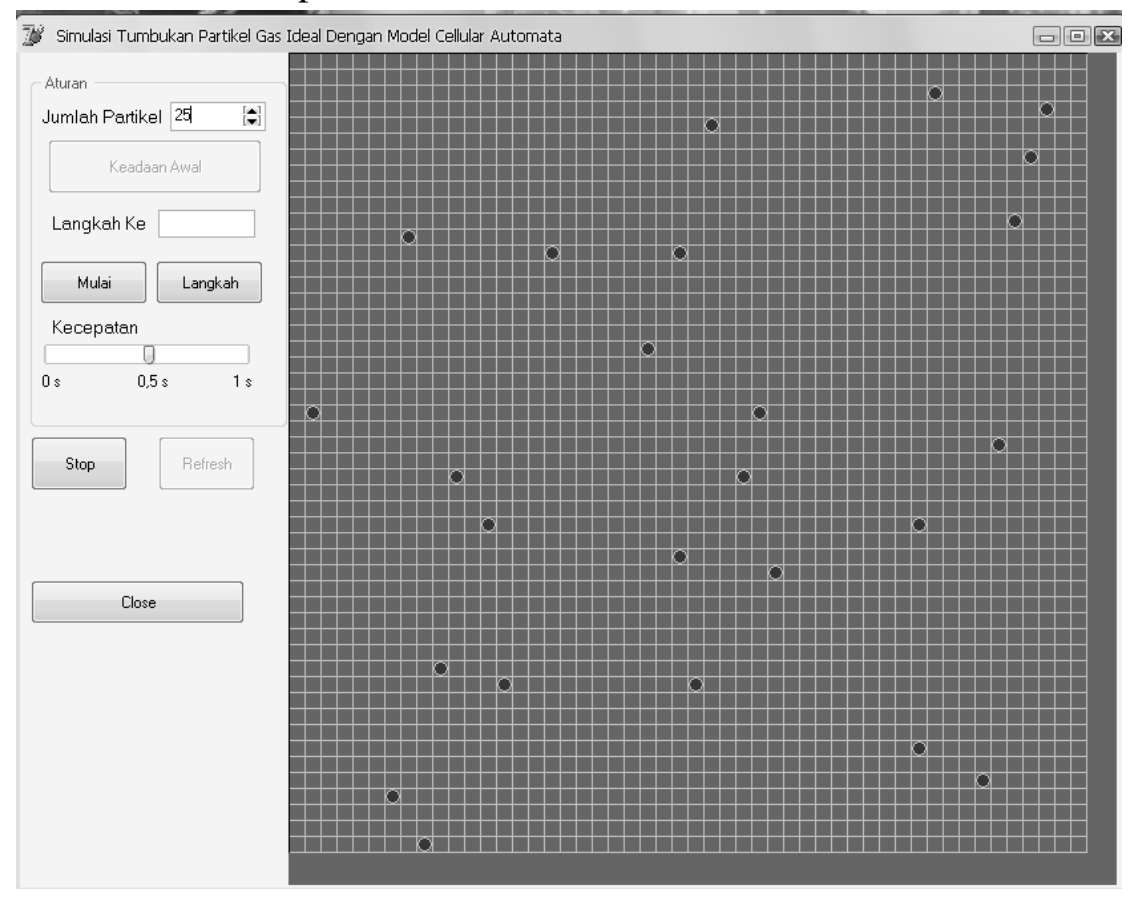

Gambar 5: Tampilan Saat Komponen Awal Ditekan dengan Jumlah Partikel 25

\section{PEMBAHASAN}

Hasil simulasi ini menunjukkan proses tumbukan partikel dengan dinding dan antar partikel. Arah gerak partikel setelah terjadinya tumbukan bergerak acak sesuai dengan aturan tumbukan partikel seperti pada Gambar 2. Partikel yang menumbuk 
dinding secara horizontal dan vertikal memantul searah datangnya partikel, Sedangkan partikel yang saling bertumbukan memantul dengan arah acak.

Pada simulasi ini partikel-partikel bergerak dan bertumbukan secara acak. Jika jumlah partikel semakin banyak maka gerak dan tumbukan partikel sedikit sulit untuk diamati. Pergerakan dan tumbukan partikel dalam jumlah besar, jika diamati tersebar tidak merata. Sebagian partikel ada yang mengumpul dan sebagian ada yang tetap bergerak sesuai dengan sifat-sifat gas ideal. Partikel yang mengumpul disebabkan jumlah partikel terlalu banyak jarak antar partikel terlalu dekat, sehingga mempengaruhi kelajuan partikel.

Partikel-partikel di simulasikan dengan jarak antar partikel lebih besar dari pada ukuran partikel, sehingga ukuran partikel dapat diabaikan. Jika jumlah partikelnya sedikit, yang terjadi hanya tumbukan antara partikel dengan dinding dan kemungkinan terjadinya tumbukan antar partikel kecil sekali. Berbeda dengan jumlah partikel dalam jumlah yang agak banyak, kemungkinan tumbukan partikel dengan dinding dan antar partikel lebih besar.

\section{KESIMPULAN}

Program simulasi partikel gas ideal dengan model cellular automata dua dimensi dengan menggunakan aturan delapan tetangga ini menghasilkan program simulasi yang gerak dan tumbukan partikel sebagian sesuai dengan sifat-sifat gas ideal dan sebagian tidak memenuhi sifat-sifat gas ideal. Gerak dan tumbukan partikel yang sebagian tidak memenuhi sifat-sifat gas ideal itu disebabkan oleh jarak antar partikel terlalu dekat.

\section{DAFTAR PUSTAKA}

Dwi Sariasih, Rujuk. 2009. Simulasi Bentuk Otot Bilik Jantung Pada Elektrodiograf Menggunakan Cellular Automata. Skripsi Fisika Universitas Negeri Malang

Halliday, David. 1999. Fisika Jilid I Edisi Ketiga. Jakarta: Erlangga

Sumarjono, dkk. 2005. Fisika Dasar I. Malang: Universitas Negeri Malang

Zemansky, Sears. 2002. Fisika Universitas Jilid I Edisi Kesepuluh.Jakarta: Erlangga 